\title{
A new species of Tenuopus Curran, 1924 (Diptera: Dolichopodidae) from Tanzania
}

\author{
Новый вид Tenuopus Curran, 1924 (Diptera: Dolichopodidae) \\ из Танзании
}

\author{
I.Ya. Grichanov \\ И.Я. Гричанов
}

\begin{abstract}
All-Russian Institute of Plant Protection, Podbelskiy roadway, 3, St. Petersburg-Pushkin, 196608 Russia. E-mail: grichanov@mail.ru Всероссийский институт защиты растений, шоссе Подбельского, 3, Санкт-Петербург-Пушкин, 196608, Россия.
\end{abstract}

KEY WORDS: Diptera, Dolichopodidae, Tenuopodinae, Tenuopus, taxonomy, new species, Tropical Africa.

КЛЮЧЕВЫЕ СЛОВА: Diptera, Dolichopodidae, Tenuopodinae, Тепиориs, таксономия, новый вид, Тропическая Африка.

ABSTRACT: A new material for the Afrotropical genus Tenuopus Curran, 1924 has been recently found and identified. Tenuopus makarovi Grichanov, sp.n. from Tanzania is described and illustrated. The new species differs from other representatives of the genus in morphology of male genitalia mainly. Correction of the last key to species of Tenuopus is also provided.

РЕЗЮМЕ: Обнаружен и определён новый материал для афротропического рода Тепиориs Curran, 1924. Описан Tenuopus makarovi Grichanov, sp.n. из Танзании. Новый вид отличается от известных, главным образом, по морфологии гениталий самцов. Приведено дополнение к последнему определителю видов рода.

The Afrotropical genus Tenuopus Curran, 1924 has been recently revised by Grichanov [2018], who has created a new monotypic subfamily Tenuopodinae for the genus and provided a key for 19 known species. Grichanov [2019] has described two more new species from southern Africa. Tanzanian fauna of the genus contains two known species, Tenuopus maculatus Parent, 1931 and T. lomholdti Grichanov, 2018. A careful sorting of Malaise traps' residues from one of the collections has revealed an overlooked specimen from Tanzania belonging to an undescribed species.

In this paper T. makarovi Grichanov, sp.n. from Tanzania is described. Now three Tenuopus species are found in the country. As a result of research from 1996 to 2020, the number of Afrotropical species of the genus has increased from seven to 22 valid names.

Holotype is housed at the Natural History Museum of Denmark, Zoological Museum, University of Copenhagen (ZMUC). The specimen has been studied and photographed with a ZEISS Discovery V-12 stereo microscope and an AxioCam MRc5 camera. Genitalia preparations have been photographed with a ZEISS Axiostar stereo microscope and an AxioCam ICc3 camera. Morphological terminology and abbreviations follow Cumming, Wood [2017] and Grichanov, Brooks [2017]. The relative lengths of the antennomeres and podomeres should be regarded as representative ratios and not measurements. Body length is measured from the base of the antenna to the tip of abdominal segment 6. Wing length is measured from the base to the wing apex. The figures showing the hypopygium and its appendages in lateral view are oriented as they appear in the intact specimen, with the morphologically ventral surface of the genitalia facing upwards, dorsal surface downwards, anterior end facing left and posterior end facing right.

\section{Tenuopus makarovi Grichanov, sp.n. Figs $1-6$.}

MATERIAL. Holotype $\mathrm{O}^{\top}$ (dried from ethanol and mounted on pin), Tanzania: Morogoro Region, Udzungwa Mt. Nat. Park, Mito Mitatu, $7^{\circ} 50^{\prime} 22.7^{\prime \prime} \mathrm{S}, 36^{\circ} 50^{\prime} 42.8^{\prime \prime} \mathrm{E}, 1325 \mathrm{~m}$, Malaise trap \#3, 5.IV.2013, T.Pape \& N. Scharff leg. (ZMUC).

DESCRIPTION. Male (somewhat discolorated). Head. Frons black, grey pollinose; one pair of short postvertical setae, shorter than uppermost postocular seta; upper postocular setae black, increasing in length upward; lateral and lower postoculars white; ventral postcranium covered with irregular white hairs; face silvery-white, 6 times as high as wide in middle, under antennae nearly as wide as postpedicel; clypeus bulging; antennae as long as height of head, yellow; pedicel projected distally on inner side, with a crown of short black setae, one of dorsal setae nearly as long as pedicel; postpedicel rounded-ovate, as long as high at base; arista-like stylus dorsal, with short hairs; length ratio of scape to pedicel to postpedicel to stylus, $9 / 5 / 13 / 79$; palpus and proboscis short, yellow, covered with white hairs, proboscis also with a pair of black lateral setae.

How to cite this article: Grichanov I.Ya. 2021. A new species of Tenuopus Curran, 1924 (Diptera: Dolichopodidae) from Tanzania // Russian Entomol. J. Vol.30. No.1. P.103-105. doi: 10.15298/rusentj.30.1.13 
Thorax. Pleura yellow; mesonotum orange, with narrow brown stripe along acrostichals, wider posteriorly and brown on scutellum dorsally; 6 dorsocentral setae with posterior pair shifted laterally; acrostichals in one regular row, strong, nearly reaching $5^{\text {th }}$ dorsocentrals; scutellum with 2 strong bristles and 2 short lateral hairs; proepisternum with 2 yellow setae.

Legs. Mostly yellow; segments 1-3 of fore tarsus mostly white; segments 1-3 at distal apex and last two segments of tarsi brown; fore and mid coxae with brown hairs anteriorly and 5-7 black apical bristles of various length; hind coxa with one long black outer bristle above middle; fore femur with short black erect ventral setae, longer at base and at apex, at most as long as diameter of femur; fore tibia simple, with 1 anterodorsal and 1 posterodorsal at base, 2 apical setae, elongate ventral hairs at base; segments $1-5$ of fore tarsus with 2 lateral rows of short semi-erect setae, longer on segments 3-4; claws simple; mid femur with anterior preapical seta, with anteroventral row of black hairs on distal half, about as long as diameter of femur; mid tibia with 3 anterior, 3 posterodorsal, 4-5 short ventral, 4-5 apical setae; mid basitarsus with several short ventral setae; hind femur with 1 strong anterior preapical seta, 2 short posteroventral preapi-
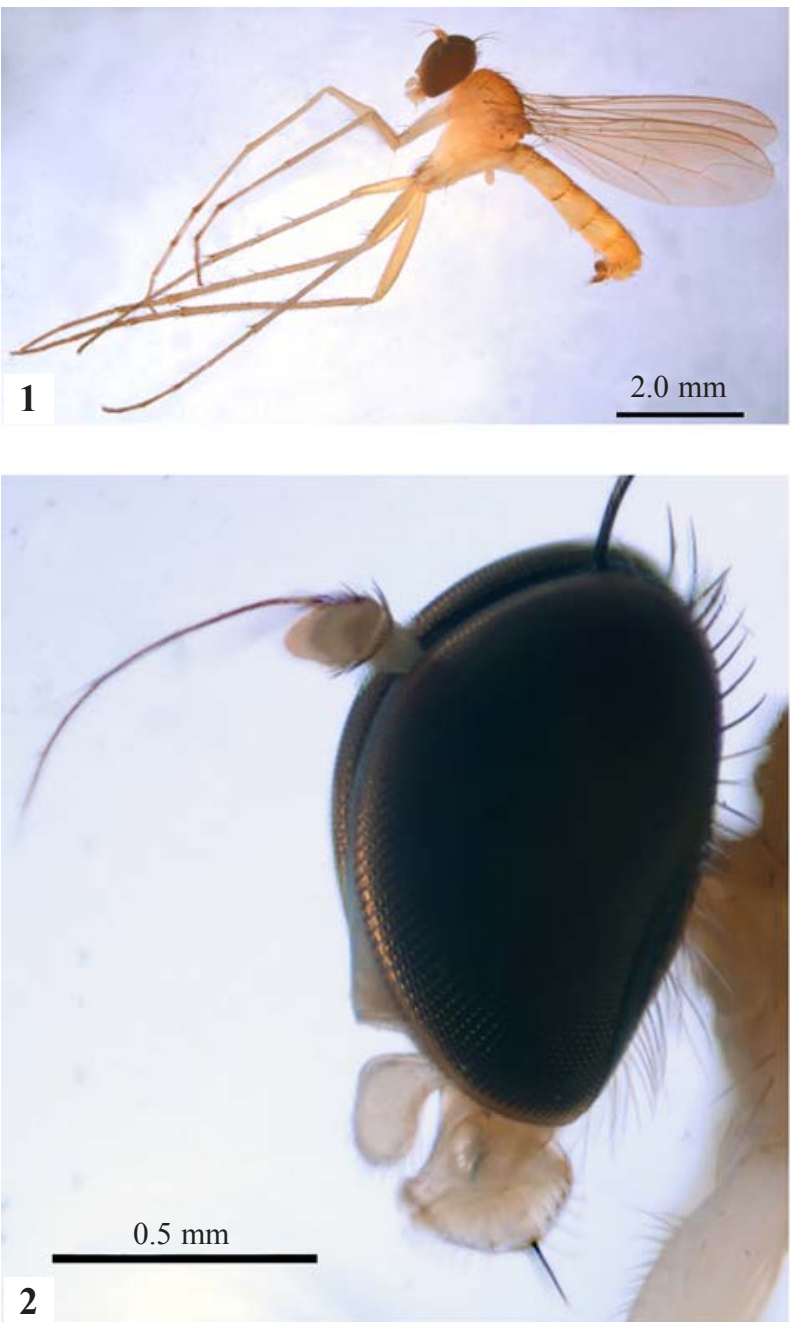

cal setae; hind tibia with 4-5 anterior, 4 short posterodorsal, 3-4 apical setae. Femur, tibia and tarsomere (from first to fifth) length ratio (in $\mathrm{mm}$ ): fore leg: 1.33/1.59/1.29/0.64/ 0.58/0.42/0.21, mid leg: $1.64 / 2.31 / 1.48 / 0.6 / 0.43 / 0.25 / 0.15$, hind leg: 1.86/3.17/0.78/0.93/0.51/0.32/0.14.

Wing. Greyish, almost hyaline, veins brown; subcosta very thin; ratio of part of costa between $R_{2+3}$ and $R_{4+5}$ to that between $R_{4+5}$ and $M_{1}, 6 / 1 ; M_{1}$ with gentle arc to apex, reaching costa right before wing apex; $M_{2}$ present as fold on membrane; crossvein $d m-m$ nearly straight; ratio of crossvein $d m-m$ to apical part of $\mathrm{M}_{4}, 0.35 / 0.76$; anal vein foldlike, not reaching wing margin; anal angle obtuse; lower calypter yellow, with black apex and pale setae; halter yellow, halter stem thin and long, with dorsal and ventral groups of short hairs distally.

Abdomen. Mostly yellow, black setose; segments 1-3 brownish dorsally, segments $2-3$ with narrow brown posterior edging; segment 6 glabrous; segment 8 and epandrium entirely yellow; segment 8 with short black setae; cercus brown, yellow at base; surstylus black; cercus covered with yellow hairs and setae; hypandrium small, simple; phallus thin and simple; 2 long epandrial lobes distally on each side;
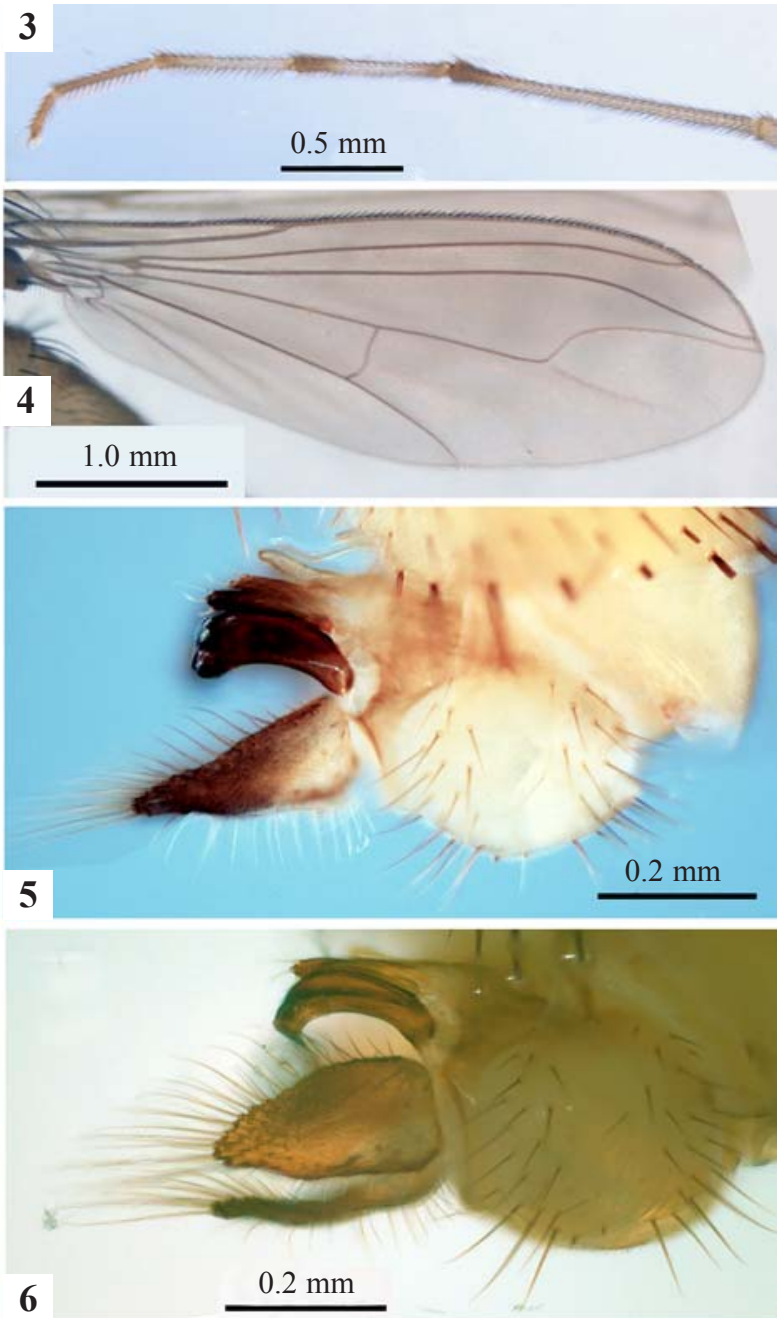

Figs 1-6. Tenuopus makarovi, sp.n., male holotype in ethanol: 1 - habitus; 2 - head; 3 - fore tarsus; 4 - wing; 5 - hypopygium, lateral view; 6 - hypopygium, dorsolateral view.

Рис. 1-6. Tenuоpus makarovi, sp.n., голотип, самец в спирте: 1 - внешний вид; 2 - голова; 3 - передняя лапка; 4 - крыло; 5 - гипопигий, сбоку; 6 - гипопигий, сверху-сбоку. 
thin epandrial lobe weekly sclerotized; thick epandrial lobe strongly sclerotized, bifurcated from middle, with $2-3$ setae at apex of each arm; surstylus shorter than cercus, cleft from distal third, with curved pointed lobes; cercus about $2 / 3$ as long as epandrium, elongate-triangular, densely covered with long light setae, longer at apex.

Measurements (in $\mathrm{mm}$, in ethanol). Body length 4.9, antenna length 1 , wing length 4.4 , wing width 1.3 .

Female. Unknown.

ETYMOLOGY. The species is named in honour of the Russian entomologist, Dr. Kirill Makarov (Moscow University, Russia).

DISTRIBUTION. Tanzania.

DIAGNOSIS. T. makarovi sp.n. belongs to a group of species with uniseriate acrostichals, being the closest to $T$. unicolor Becker, 1914, differing from the latter in smaller size, male postpedicel not longer than high; cercus distinctly shorter than epandrium, elongate-triangular [Grichanov, 2018], differing also in setation and length ratio of fore tarsomeres and morphology of hypopygial appendages (see key below).

5. Acrostichals strong, extending to posterior third of mesonotum; segments $3-5$ of fore tarsus with rows of strong setulae $5 \mathrm{a}$

- Acrostichals weak and restricted to anteriormost of mesonotum, or absent; at least segment 3 of fore tarsus without strong setulae

7

5a. Fore basitarsus 2 times longer than segment 2; cercus shorter than epandrium; body $4.9 \mathrm{~mm}$

T. makarovi sp.n.

- Fore basitarsus 1.3 times longer than segment 2; cercus 2 times longer than epandrium
6. Postpedicel oval, longer than high; cercus band-like, almost evenly wide; body $6 \mathrm{~mm}$.

T. unicolor Becker, 1914

- Postpedicel subtriangular, as long as high; cercus broadest in basal half; body $7 \mathrm{~mm}$.....

T. shcherbakovi Grichanov, 1996

Acknowledgements. The author is sincerely grateful Dr. Thomas Pape (ZMUC) for his kindness in furnishing an opportunity to study the collections of his Museum. The work was supported by the All-Russian Institute of Plant Protection project No. 0665-2019-0014.

\section{References}

Cumming J.M., Wood D.M. 2017. 3. Adult morphology and terminology // A.H. Kirk-Spriggs, B.J. Sinclair (eds.). Manual of Afrotropical Diptera. Vol.1. Nematocerous Diptera and lower Brachycera. Suricata 4. Pretoria: SANBI Graphics and Editing. P. 89-134.

Grichanov I.Ya. 2018. A new subfamily of Dolichopodidae (Diptera) for Tenuopus Curran, 1924 with description of new species from Tropical Africa // Far Eastern Entomologist. No.364. P.1-25.

Grichanov I.Ya. 2019. New Afrotropical species of Tenuopus Curran, 1924 (Diptera: Dolichopodidae) // Russian Entomol. J. Vol.28. No.4. P.460-463.

Grichanov I.Ya., Brooks S.E. 2017. 56. Dolichopodidae (longlegged dance flies) // A.H. Kirk-Spriggs, B.J. Sinclair (eds.). Manual of Afrotropical Diptera. Vol.2. Nematocerous Diptera and lower Brachycera. Suricata 5. Pretoria: SANBI Graphics and Editing. P.1265-1320. 